\title{
Circuit
}

Musiques contemporaines

\section{Comments by Tan Dun on His Music}

\section{Shawn Mativetsky}

Volume 12, numéro 3, 2002

La route de soi

URI : https://id.erudit.org/iderudit/402002ar

DOI : https://doi.org/10.7202/402002ar

Aller au sommaire du numéro

Éditeur(s)

Les Presses de l'Université de Montréal

ISSN

1183-1693 (imprimé)

1488-9692 (numérique)

Découvrir la revue

Citer ce document

Mativetsky, S. (2002). Comments by Tan Dun on His Music. Circuit, 12(3), 35-44. https://doi.org/10.7202/402002ar

\section{Résumé de l'article}

Invité d'honneur du festival Musimars 2002 à l'Université McGill, Montréal, le compositeur chinois Tan Dun y donnait, entre autres, une conférence sur son oeuvre qui s'est transformée en un passionnant dialogue avec l'auditoire. Nous avons retranscrit ses propos sur sa musique, ses influences, son cheminement et ses impressions sur la musique occidentale.
Ce document est protégé par la loi sur le droit d'auteur. L’utilisation des services d’Érudit (y compris la reproduction) est assujettie à sa politique d'utilisation que vous pouvez consulter en ligne.

https://apropos.erudit.org/fr/usagers/politique-dutilisation/ 


\title{
Comments by Tan Dun on his Music
}

\author{
Transcribed and edited by Shawn Mativetsky
}

Please note that this text has been altered from the original transcription so as to flow better in written form. The transcriber has attempted to maintain Tan Dun's original flow of ideas, meaning, and personality.

Presented during the Musimarch festival, on March 6, 2002.

McGill University Faculty of Music, Montreal.

Moderator: Don Mclean.

Tan Dun - I don't think that we should call this a lecture, but rather a dialogue. So, if you don't mind, I'd love to share with you the many things I have done, am doing, and want to do. Some of them are good, some of them are perhaps not so good, or even bad.

In any case, I find that through my culture and my experiences, I have learned the most through sharing, and I want my music to be shared. As many composers who are here today may have experienced, I was afraid of a lot of things in my career. I was afraid that my music would be considered to be beautiful, melodic, or tonal. I was afraid to be Chinese, afraid to be American, or afraid to be, you know, many things. But later on, I asked myself, "Why?"

I find that music is a most international language, but as a business, it is sometimes divided and isolated. A younger generation never seems to figure out why parents like one kind of music and the parents have no idea why their kids love another. Of course, this phenomenon is not limited to the family unit. It can also be observed in schools, in music circles, professional circles, and among conductors, orchestras, and performers. Each person has his own idea about how the music should be played. I find that today, everything is changing, and it is changing in a way which has never happened before in our history. If you consider eating habits: 
if someone says, "I only eat Sushi," that person has a problem. We all eat all sorts of things; we have so many choices, as we have in music too. Today's society has so many choices, more than in any period in history; more than in any country or culture. What I want to share is how and why we're doing music today - what is the future? And, what is our personal practice regarding these things? I want to hear more from you, and relate and elaborate upon your points and my points.

In general, my music is not about complexity or simplicity. It is not about East or West. It is not about modern or traditional. It is about people; that something can always be shared. That's why I told you I want to share, today, right now. Let's have a dialogue rather than a lecture because I don't have anything to lecture about here. What l'm doing is simply being a musician. I'm not a philosopher, I'm not a god. I just write music as you would write a letter or an article; it's all communication. The things that induce me to write music still continue in me because it's something very very shareable.

The first thing I want to share with you is who I am and where I came from. I came to the United States 17 years ago. As composers, like Bartók, have collected folk songs in the field, I too have benefited from such activities. Even now, I continue to do so once a year, or so. I felt that I needed to touch real life. The videotape that I want to share with you is from a couple of years ago, when I went back to the hometown area of my birthplace. I was born in Hunan. There are two very famous people from Hunan: Mao Tse-Tung, and the other one is... me [laughter]. I say that because Hunan is a place with a lot of minority people, minority cultures, including mountain aboriginal people. The culture there is very earthy and authentic; this is what I grew up with. So after 30-something years, going back again to collect folk songs and folk art, reminds me about who I really am.

\section{[...]}

I never heard Western music until I was about 18 or 19 years old. We didn't have Western music or Western instruments at all. During the Cultural Revolution, it was banned; Western music was not allowed to play. So, when the Philadelphia Orchestra visited China, right after Nixon's visit, that was my first time ever hearing the name of Beethoven, and his music. When I first heard the music of a Western orchestra, I was quite surprised because of wo things. Number one, how does this orchestra hold a pitch so very flat? Because our music always sounds like calligraphy [imitates a Chinese instrument with heavy vibrato]. The other thing was, that it was so loud! It could be so powerful. As a child, as a wild child, I was immediately seduced by this media, by the orchestra. So, from that time, I wanted to write for orchestra; I wanted to be a composer. That's why even today I am still mainly working with this media. Of course, unfortunately, this media, the orchestra, or Western instruments in general, is so far the most marketable, travelable, or shareable media. It would not be possible to have this village band's music played by American, or other musicians. It has made me consider another interesting point: if 
I compose for this Western-style orchestra with my own experience, from another angle, then I find that this orchestra is new; it's a totally new thing which may be facing another few hundred years of further development. For example, in the Orchestral Theatre series, which you are going to hear tomorrow night, I was trying to compose for this few-hundred-years-old Western, romantic, traditional orchestra, but from a different cultural angle; a different sonic point of view, with different combinations. I find that there are unlimited colours to discover that could make this orchestra into a totally new, invented ensemble. The point is how you find the angle, how you find the inspiration. That's why I sometimes go to different places to collect folk sounds and the folk music, but the most important thing is to collect the spirit. Last month, for instance, I finished my new opera. It's called A Tea, which is an opera taking place a few thousand years ago, when human beings started to discover tea. And, of course, because of writing a tea opera, I started to do tea research and field work. I did a lot of tea bath research and tea ceremony research in different countries. I learned so many things.

Audience - l'd like to know if you have a concern, and maybe this is why you're saving, collecting these folk songs. Are you concerned about the influence of the West getting into your hometown at some point and changing it?

Tan Dun - Actually, I'll tell you; there's another interview we did, where I mention this story: Tomorrow night, you will hear David Cossin, who is a New York-based percussionist. The most touching experience in my musical life was to see the first time that David met these people in London [musicians from Hunan]. They don't speak the same language so they could not talk. They suggested to me, why not let them talk through their music? Then they started to improvise logether, and the good thing is, all the farmers from our province [Hunan] started to fight because they each wanted to be the first one to improvise with David. Then David asked him, "What shall we improvise?" You know what this farmer's answer was? He said, "Wind." David said, "WHAT?!" The farmer responded, "Let's play wind on drums." Interesting. Then the same thing happened with the cellist, Maya Beiser. We also toured with the Shanghai Symphony Orchestra and went to my hometown. We also played the music for them, and they loved it. In some cases, my music was re-conceived and composed into a contemporary piece, based on music I learned from people in Hunan. When I played it back for them, they loved it. They can accept it and actually feel very close to it. It's interesting. It's a very convincing process.

I also want to do a project with the local cultural people and the local village. Not just in this village, but to use it as a model for a festival open to composers, conductors, and musicians. The idea is to gather three, eight, or ten international musicians: a conductor, a composer, and a performer, and to perform all kinds of international music. To live there for a couple of weeks and get a commission to 
write new music about what they learned or what they collected there. In the second year, they would go back again to play their commissioned work there.

To answer your question: I think it's very inferesting - they accept; they are very open, actually. What I learned from those people is that they are very free. As I said a couple of nights ago, I find that for an artist, the most important thing is freedom. Sometimes in China, we feel frustrated because when you want to do a concert or a festival, you have to get everything approved; it's frustrating. This is a freedom issue and we have this - in the Western world, we are free! But then I find, we are free from society, but it does not actually mean that everyone is free inside; and how much freedom can you give to yourself? That's more important, actually! For example, Shostakovich might not have had as much freedom as John Cage did here, but actually he had the freedom within himself. He wrote a lot of things still reflecting the human soul and the human heart. Be avant-garde, be spiritual, and truly be yourself. You need freedom from yourself too. I remember when John Cage talked to me a long time ago. He said, "You know, to be a good composer, you don't just need a good imagination, good technique, and good experience. The most important thing is: you need courage. You need encouragement from yourself. You should be able to do anything." So that's the feeling I get from those people. They are so free. When they heard Western music, they loved it so much, and they want to try it, they wanted to play with them [the Western orchestra]. They immediately feel that this is nalurally part of their life.

Audience - Tan, you were talking about freedom and artistic freedom. I wanted to know: when you're doing your film scores, how do you treat them differently than concert scores. Because, if you wrote what you would write for the concert hall for Crouching Tiger, Hidden Dragon, umm...

Moderator - I think the line was, you'd get fired, right?

Audience - I'm just curious - how do you gratify yourself as an artist in terms of that medium?

Tan Dun - As you know, I came from this kind of culture. Then, after a few years, I jumped completely into the Western music sea and I totally forgot about those things from my past. When I was at the China Conservatory II spent about eight or nine years there), I wanted to be a Beethoven, Lutoslawski, Stravinsky, Pierre Boulez, or Messiaen. I wanted to be this kind of thing. I wrote atonal, I wrote contemporary. I suddenly realized: I'm a contemporary composer, as an American. So, I came to New York. I wanted to learn about more advanced technology, and about music. Later on, I found out that music is not about technology at all. In that period, I was, like many of you here perhaps were, afraid of people saying that my music was too melodic, too beautiful, too rhythmic, too regular, too colourful, too many visual hints, and not abstract enough. I was also afraid when people asked me to write film music. I was afraid because I thought that if I write film music, something might be de-qualifying my composing ability. Now I'm not. 
Specifically, I was afraid of simplicity, I think I'm always complex in a way. Later on, after a few years in New York, when I met John Cage in 1988, I remember, he started to talk to me about American culture, about / Ching, specifically. As a Chinese person listening to an American teaching me about / Ching, it was great, really shocking.

From there, I started to change. In my first three years at Columbia University, I wrote a string quartet, a violin concerto, and many other chamber music pieces, more or less based on atonal principles. Sometimes you can hear the struggle, the atonal struggling with these concepts, unconsciously inside of myself. By 1990 , more or less, I think I overcame this fear, and reviewed myself. That is why I composed an organic opera using all self-made instruments: ceramics, bamboos, wood, metal, etc. I was imagining a 2000 year-old opera performed like this, and that's a statement. From there, I started to compose my first Orchestral Theatre piece, which you're going to hear tomorrow night, using orchestral force to perform an ancient ritual. Musicians are not just playing, but also shouting, singing, and playing as a whole.

I have known Ang lee for many, many years. So when we have a party, like a New Year's parry, we are always singing together. Once, about four or five years ago, when Ang Lee was still doing lce Storm, he asked me if I would like to compose a film score for him. I asked, "what kind of film?" He said, "it's a martial arts film." I said, "WHAT?!" Because personally, I don't particularly like the typical Hong Kong martial arts film genre. But he said, "It's not typical; it's more cultural and philosophical," so I started to get involved. Next, we talked about having Yo Yo Ma, in order to link things in the film from the East to the West. It was a big leap. Later on, I found out, that to write film music and concert music is totally different. If you write film music the same way that you write concert music, you will be fired immediately. It is different. But, what are we going to do? Film music is very tough; it is very difficult to write. First of all, you need skill; you need technique; you need to be fast. For example, for Crouching Tiger, I was only given about two weeks, about ten days actually. It's nearly 90 minutes of music. You have to do it without thinking; you just unconsciously write and write. And whatever comes out from your mind is going to be printed out in those pictures, just like that. Secondly, you have to create an underlying language. For example, when the main character is laughing, yet the music must evoke tears. There are a lot of things that the director cannot say, but that the music must say. The music must also create rhythm, to help the function of movement. If's all happening in the music. It's very very important. We can have a lecture, specifically talking to composers about how to write film music. It's very very interesting and very very tough.

To come back to the original subject, Beethoven used to be commissioned only by symphony orchestras and occasionally opera houses. Later on, Stravinsky started to get involved with ballet. But what we are involved with today is not just the symphony orchestra and opera houses. If you want to be a real composer, to 
serve our people and our society today, I am sure that you also want to be involved with television, pictures, Internet, film, etc. It's a new thing in our technological era. A long time ago, I was afraid of being commissioned to do film music, but l'm sure that in the next decade composers will be afraid not to be commissioned to write film music or television music, because that's the future. The focus is: how can we write better, how can we make film music more artistic, and how can we make concert music more conceptual?

People sometimes have doubts about contemporary music; I see: I'm a contemporary composer too. Honestly, it's not because they don't understand contemporary music. I think that contemporary music these days is not providing enough of a challenge; it is not interesting. I tell you, a lot of people frankly say, "It doesn't matter." You know, we sometimes spend so much time writing a piece, and then someone from the younger generation will say, "why are you doing this? You think it's very arty, avant-garde, and so on, but to us, it's not a big deal, it's not interesting, it's not really talking to us, and it's not really powerful enough to grab my attention." So then, how can we make our concert work more conceptual, more challenging, or be more challenged ourselves? I think we need to go back to the roots, to the life. This is what I'm doing now. I find that in the 1970s and 1980s we used to find our inspiration from technology, from techniques. Today, it's impossible to find any kind of techniques or technology that has never appeared, or been mentioned, or practiced in some music. Can you find anything that no one has tried before? Impossible. But life is something that never repeats. That's my laser way. I don't want to spend too much time in the studio, or at the table writing serial music or counterpoint, or coming up with a certain motif, or whatever; I just go, go to travel, and meet people, see the improvisations, or have a drink in a jazz bar. I get a lot of input and I start to think about how I can create some challenging things because those things challenged me.

\section{[...]}

Audience - There are a lot of people in China saying that Crouching Tiger is a Chinese film that caters to a Western market. It doesn't matter if that's the case or not. So when you created the music for the film, did you have a Western market in mind? And especially when you blend foreign or Chinese musical elements into the music, do you cater to Western taste? Is there a relationship between the Chinese artist and the Western market, and the challenge?

Tan Dun - My answer is no because I don't have boundaries in my heart, especially with regard to music. That's how I benefit. For example, I composed another film soundtrack, which stars Denzel Washington; it's called The Fallen (lit's a little bit spiritual, a little action.). For that, I mainly used didgeridoo for the theme, from the aboriginal people [of Australia]. It's a kind of suspense film. I have sometimes received this kind of question from Chinese people. They also ask, "Is this movie really made for Western people?" | say, "First of all, it's not, but if it is, so what?" 
[laughs] Because that's the major market for film, I tell you. China is the biggest country [in terms of population], but at this moment, the marketing for film is very tiny. An entire year's box office returns in China are only equal to those of New York City. The Chinese film market cannot feed Chinese directors at all. What are we going to do? If millions of people enjoyed Crouching Tiger, why do I have to feel guilty? [laughter] Of course, we didn't plan it that way, not at all.

Ang lee filmed the Gobi Desert, the southern villages, bamboo forests, the forbidden cities of the north, and other story-related sceneries. He asked me, "Is there any way that you can find a bridge, a musical bridge to link all those things together? I have a little problem, I feel a danger that things will seem too far apart." Then I said, "Why don't we use Yo Yo Ma?" He asked, "Why Yo Yo Ma?" I said, "Because Yo Yo Ma's cello is very interesting, not just because he can play Bach (music's past) so well. His cello is so charming because he can play music's future." So he can play Mongolian fiddling, American fiddling, Chinese fiddling, Baha fiddling, or any other sort of fiddling. His cello can stop sounding like a cello, and can sound like anything. The sound is drawn from many sources, and condensed onto one cello; it's very interesting, also from a classical music point of view. Tomorrow night you will see that this cello fiddling is really making the cello sound more interesting (please pay special attention to the cadenza part). I am very satisfied with this, you know. As I mentioned before, film music must be very simple, and very directly communicated. The melody and harmony must be very regular. How could you make things a little bit irregular and more challenging? I think that what I did, by using this most popular instrument, the cello, but in doing most unusual multicultural fiddlings, these fiddlings will enlarge the colour of the cello, expand the life of the cello, and, using these magical sounds and colours of the cello, seduce and challenge people.

Audience - You talk a lot about the cultural influences on your music and how your music is supposed to say something to certain groups of people. I'd like to know what you think the relationship is between your music and the people who listen to it.

Tan Dun - I just did a concert with the Los Angeles Philharmonic, and that day John Williams came. He was talking to me backstage and said, "lt's very interesting. I am always seeing so many young people at your concerts." I said, "That's the purpose. I really want to compose to challenge the younger generation because I find what I'm doing is pretty close to their lifestyle." I like to see their way to wear clothes, to eat, to watch things, you know. I'm a father now, so I'm trying to pay attention to my son: how he behaves, what he wants, how he communicates. I cannot communicate with him using only my methods. I have to see how he wants to communicate. By paying attention to his method of communication, I can be quite successful. With music, it's the same. You can be very successful in communicating with the younger generation. Breaking boundaries has given me a freedom and the ability to focus on the younger generation, to bring them to the 
classical music hall, and create an interest in contemporary music; this is really my first priority.

Audience - What do you do with them once you've got them in the concert hall?

Tan Dun - To present them with all kinds of fiddling on the cello. [laughter]

Audience - You can bring people into the concert hall, but I find that the challenge of the composer is always: what do you say to them once you've got them there?

Tan Dun - Yes. To say. I think that to say is another thing. With music, it's very tough because if you want to say something about other peoples' feelings, then people don't like it. I find it's very interesting: the phenomenon of art appreciation, whether it's visual art or musical art. The audience always comes and wants to personally share what the creator wants to show, but it does not necessarily mean that his composition reflects him personally. Some of my music, I don't feel that it perfectly represents me. For example, when the British handed over Hong Kong to China, they had the big festival, where I presented Symphony 1997. To me, it was a big occasion. I love what we did; a big, peaceful event. But that event also required me to write for the celebration. There are many many of my personal feelings in it, but it's only half and half.

\section{[...]}

I think we need to think about the purpose of making music. I think first of all, that this is a very very personal issue. I told you that my understanding, my study of music is that music is not about technology, or techniques; it is not about the West and the East, or complexity, simplicity, or whatever. It doesn't matter. The whole phenomenon of music is communication. It is a business of communication, you know. Before language, when animals wanted to make love they said, "Boom boom boom boom boom boom, $\mathrm{COO} \mathrm{cOO} \mathrm{COO} \mathrm{cOO} \mathrm{cOO} \mathrm{cOO}^{\circ}$." That's how animals started to sing. That's the whole purpose and if we don't communicate, we don't have to make music. We can do something else: cook, eat, work, etc. So, if we think that music is really a communication device, then technically we have to make it very challenging and then people will want to come to concerts to share and be challenged.

Audience - I'm wondering about movement. When we saw the two musicians with the cymbals or the flute, they're turning around [referring to the video played earlier in the lecture]. How does the movement of the body influence the sound? Sometimes you see what you communicate. I was just wondering how you use this, and also in the movie Crouching Tiger, you must have seen some of the rehearsals, or some of the movements, the artists...

Tan Dun - Wonderful question, because actually, that's why I'm not just interested in concert music, or even if I am composing a concert work, I'll always be influenced by this kind of life in the village. For example, the Crouching Tiger Concerto 
that you are going to see tomorrow night has two segments: you will see the percussion soloist, and the bamboo flutist travel; they will move. They will play with the body. This is part of the experience. It's very interesting that the music played as we see in the concert hall is only a few hundred years old. The history of classical music was developed in the court, and in the church; until now, this has been the standard format. But think about the millions of years over which music was invented. And we have so many formats of playing: look at rock ' $n$ ' roll and jazz. Why does classical music have to be presented in this one format, as defined by these few hundred years of history? Why don't we liberate ourselves to do whatever is most reasonable, playable, or economical. I think that we are facing a major revolution for classical music in this century. I am sure. The way of writing, the way of combining all kinds of sounds and instruments, even the placement of the orchestra, and the design of the concert hall. I think that the concert hall of today doesn't work because we need to have a new concert hall. I am sure that this is going to happen in the next few decades.

Moderator - It's happening right here [at MCGill University] as people may or may not know. We're designing a new building right now and one of the big rooms in this is in fact a film scoring stage, and since McGill specializes in Internet broad. cast, one of the things that will happen is that it will be a hall, as we say, with real musicians and a virtual audience. We'll be able to go technologically pretty well anywhere in the world with this hall and record the sound and broadcast the sound, and do this because we feel that this is what young musicians need to learn how to do, what young technicians need to learn how to do, and we feel very much that that's part of the future.

Tan Dun - From my experience, I find that the move from conservatory or university life into society is totally abrupt. I spent so much time in school: almost nine years in the conservatory in China, seven years at Columbia University, plus the pre-conservatory years I spent in high school - all together about 30 years. If the school system can become more unique, better reflecting what's happening in society, you will survive. It would be more interesting. Aside from learning techniques, we should just be thinking about, always thinking about, why we make music. Always put up this big umbrella and make yourself much freer. Also, I think that roots are very important, and that the tree keeps growing. You know, if you want to have many leaves, then you have to have deep roots. That's what I really want to say. Thank you so much. 


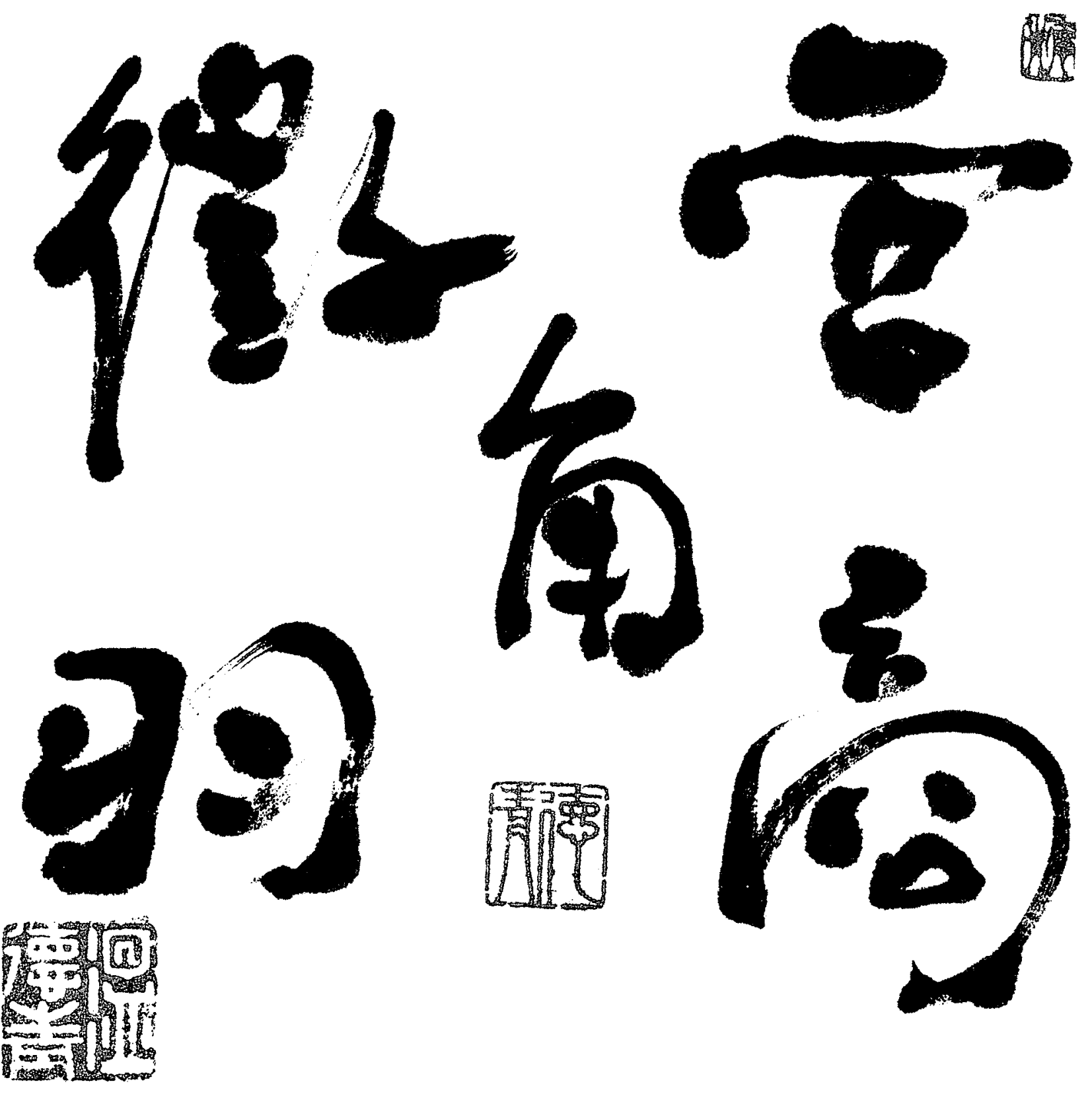

